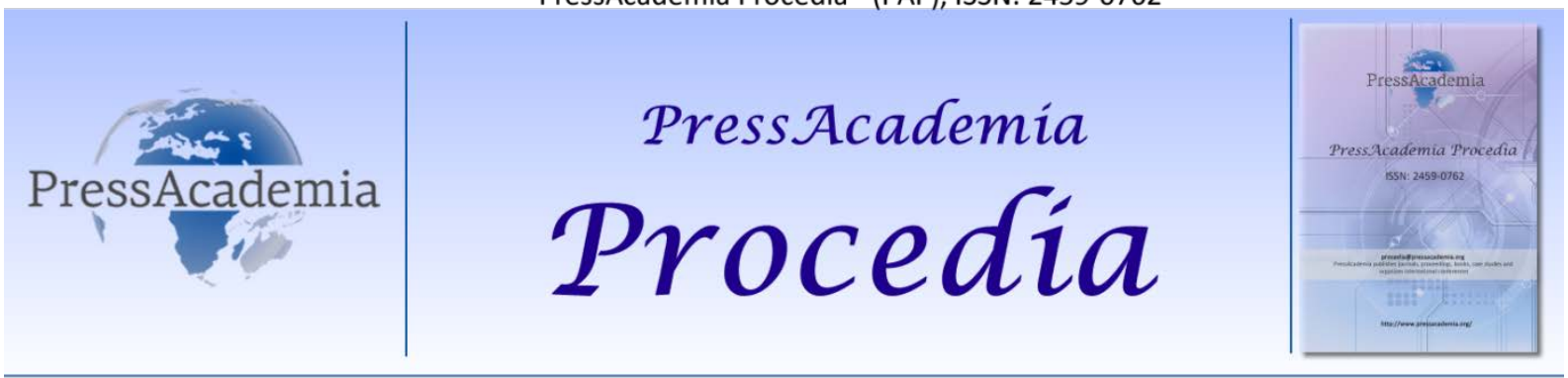

Global Business Research Congress (GBRC), May 26-27, 2016, Istanbul, Turkey.

\title{
A STUDY ON THE FACTORS INFLUENCING THE PREFERENCE OF ISLAMIC BANKING
}

\section{DOI: 10.17261/Pressacademia.2016118677}

\author{
Ismail Yildirim ${ }^{1}$, Recep Cakar ${ }^{2}$ \\ ${ }^{1}$ Hitit University, ismailyildirim@ @itit.edu.tr \\ ${ }^{2}$ Hitit University, recepcakar@hitit.edu.tr
}

\begin{abstract}
Participation banks operate according to the interest-free banking principle and raise fund from financial consumers in line with this principle in order to use the funds they collect. The number of financial consumers who prefer Islamic banking in Turkey has been rapidly increasing recently. This study investigates the factors influencing the way financial consumer regard participation banking having developed a model called Islamic Finance Acceptance Model. Service quality, religious sensitivity, awareness, developed four hypotheses regarding transparency and accountability. Surveys were developed in order to collect data online and they were delivered to academics working in Turkish universities. 708 questionnaires were included in the analysis. According to the results of the financial consumer service quality perception it is the most important factor affecting participation in usage intentions. Awareness, Transparency and accountability are the other factors that affect the use of participation banking intentions. Unlike the religious sensibilities are not supposed participation banking have an impact on the intention to use.
\end{abstract}

Keywords: Financial customer, İslamic Bank, participation bank, Turkish İslamic Banking Sector JEL Codes: G21, G02

\section{KATILIM BANKACILIĞI KULLANIMINI ETKILEYEN FAKTÖRLERE YÖNELIK BIRR ARAŞTIRMA}

\section{ÖZET}

Katılım bankaları faizsizlik ilkesine göre çalışırlar ve finansal tüketicilerden bu ilke çerçevesinde fon toplayıp fon kullandıırlar. Son yıllarda Türkiye'de katııım bankasını tercih eden finansal tüketici sayısı hızla artmaktadır. Bu çalışmada, İslami Finans Kabul Modeli olarak adlandırılan bir model geliştirilerek finansal tüketicilerin katıım bankacılığına bakış açılarını etkileyen faktörler araştııılmaktadır. Hizmet kalitesi, dini hassasiyet, bilinirlik, şeffaflık ve güvenilirlik ile ilgili 4 hipotez geliştirilmiştir. Veriler hazırlanan anket formu aracıllğıyla Türkiye'nin çeşitli üniversitelerinde görev yapan akademik personele online olarak uygulanmışır. 708 anket analize dâhil edilmiştir. Anket neticesinde toplanan veriler Yapısal Eşitlik Modeli yardımıyla test edilmiştir. Analiz sonuçlarına göre finansal tüketicilerin hizmet kalitesi algııı katılım kullanım niyetini etkileyen en önemli faktördür. Bilinirlik, Şeffafık ve güvenilirlik katııım bankacılı̆̆ı kullanım niyetini etkileyen diğer faktörlerdir. Dini hassasiyetler ise sanılanın aksine katılım bankacılığı kullanım niyeti üzerinde bir etkiye sahip değildir.

Anahtar Kelimeler: Finansal tüketici, İslami Banka, katılım bankacılığı, Türkiye İslami Bankacılık Sektörü JEL Kodları: G21, G02 


\section{GíRiş}

Dini inançlar bireylerin sosyal yaşamlarının yanı sıra finansal kararlarında da etkilidir. İslam inancına göre faiz kazancı elde etmek haramdır. Bu dine mensup pek çok insan tasarruflarını değerlendirirken faizden kaçınmaktadırlar. Bu tür hassasiyete sahip tasarruf sahipleri faizsiz finans enstrümanlarına yatırım yapmaktadırlar. Uluslararası alanda İslami bankacılık olarak geçen katılım bankacılı̆̆ı, faiz getirisi elde etmek istemeyen finansal tüketicilerin tercih ettiği bankacılık türüdür.

1970'lerin ortalarından günümüze kadar İslami bankacılık hız kesmeden büyüdü. İslami bankalar zamanla küresel finansal piyasaların önemli birer aktörleri olmuşlardır(Mallin, Faraga and Yonga, 2014). İslami bankaların çalışma prensipleri arasında kar ve zararın paylaşılması vardır (Bellalah and Ellouz, 2004). Küreselleşme süreci ile birlikte İslami bankalar verimliliklerini artırmak ve sürdürülebilirliğini sağlamak için performanslarını geliştirme çabası içinde bulunmuşlardır (Mghaieth and Mehdi, 2014).

Son yaşanan küresel mali kriz (mortgage crisis) yatırım ve bankacılık açısından İslami finansı alternatif bir seçenek olarak gündeme getirmiştir (Smola and Mirakhor, 2010). Özellikle son bankacılık ve finansal krizlerden olumsuz etkilenmeyen İslami bankacılık sektörü küresel mali yapının bir parçası haline gelmiştir (Aldohni, 2015). İslami bankacılık dünyanın diğer bölgelerinin aksine özellikle Orta Doğu ve Güney Asya'da büyük ivme kazanmış ve kabul görmüştür (Ariff, 2014). Bu gelişmenin en önemli nedenleri arasında Müslüman nüfusun yoğun olarak buralarda yaşamasıdır.

Dünyada günümüze kadar birçok finansal kriz meydana gelmiş ve sisteme farklı finansal araçlar girmiş sitem dinamik hale gelmiştir. Bu sebeplerin yanında dini sebepler nedeniyle de 1960'lı yıllardan itibaren finansal siteme katılım bankacılığı ürünleri de dâhil olmuştur. Günümüzde hızla gelişen katılım bankacılığı sadece İslam ülkelerinde değil Avrupa'da ve Amerika'da da finansal sektörden aldığı payda her geçen gün artmaktadır.

Türkiye'de katılım bankacılığı faaliyetleri 1985 yılında özel finans kurumları olarak başlamış 2005 yılında katılım bankacılığı adıyla devam etmiştir. Türkiye'de şu anda 4'ü özel sektöre ait 2'si devlete ait 6 katılım bankası faaliyette bulunmaktadır. Katılım bankacılığı ismini aldığı 2005 yılından itibaren şube sayısında \%410, personel açısından \%370'lik, bir artış kaydedilmiştir. Aktif büyüklüğü açısından ticari bankacılık sektöründe \%370'lik büyümeye karşın katılım bankacılı̆̆ında \%860'lık büyüme gerçekleşmiştir (Toroman vd., 2013). 2015 yılı aktif toplamı 2 trilyon dolar olan katılım bankacılığı aktif toplamı Türkiye'de 115 milyar TL aktif büyüklüğüne ve 1116 şube ile 14.000 çalışan sayısına ulaşmıştır. (TKBB, http://www.tkbb.org.tr/veri-seti)

Katılım bankacılığının Türki Bankacılık sektöründeki bu hızlı artışı hem kurumsal hem de bireysel müşterilere farklı finansal ürün sunmuştur. Bu bilgiler ışığında Türkiye'de katılım bankacılığının gerek faizli bankacılıkla rekabet etmesi gerekse katılım bankacılığı uygulamalarının farkındalığının artırılması sağlanarak reel sektöre kaynak temini amacıyla önem taşımaktadır.

Türkiye'de 2'si son yıllarda faaliyete başlayan kamu sermayeli olmak üzere 6 katılım bankası faaliyet göstermektedir. Kamunun katılım bankacılığı sektörüne giriş yapması sektöre büyüme ivmesi katacağı düşünülmektedir. Katılım bankaları gelecek yıllarda bankacılık sektöründe aldıkları payları daha da artırmayı planlamaktadırlar. Katılım bankalarının bankacılık sektörü içindeki payını artırması demek daha çok mevduat bulmaları anlamına gelmektedir. Daha çok mevduatı da daha çok finansal tüketiciyi katılım bankalarına çekerek sağlayacaklardır.

$\mathrm{Bu}$ çalışma, finansal tüketicilerin katılım bankacılı̆̆ tercihlerini etkileyen faktörleri tespit etmek amacıyla yapılmıştır. Çalışmanın birinci bölümünde araştırmanın modeli ve hipotezleri hakkında bilgi verilmiş, daha önce yapılmış olan çalışmalara değinilmiştir. İkinci bölümde ise Türkiye genelinde üniversitelerde çalışan akademik personele yapılan anket sonuçlarına yer verilmiştir. 


\section{LITERATÜR TARAMASI}

Literatürde katılım bankacılığına yönelik yapılan çalışmalar yer almaktadır. Katılım bankacılığının sektördeki algısını anket aracılı̆̆ıyla tespit eden çalışmalar arasında; Gençtürk ve Çobankaya (2015), Toroman vd. (2015), Çobankaya (2014), Özsoy vd. (2013), Kaytancı vd. (2013) yer almaktadır. Uluslararası çalışmalar arasında ise; Ramadan (2013), Khattak ve Rehman (2010) yapmış oldukları çalışmalar ile Metawa ve Almossawi (1998) yapmış olduğu çalışma yer almaktadır.

Gençtürk ve Çobankaya (2015) çalışmaların da, katılım bankaları müşterisi olan ve katılım bankalarıyla hiç çalışmamış olan kişilerin katılım bankacılığı sistemi konusundaki algıları ölçülmüştür. Çalışmada katılım bankası müşterileri katılım bankalarının işlemleri kısa sürede yapması, güvenilir olmaları, hizmetlerin kaliteli ve pahalı olmaması, çalışanların saygılı ve nazik olması, yenilikçi olması ve dini sebeplerden dolayı tercih ettiğini belirtmiştir. Ayrıca katılım bankacılığını kullanma sebepleri sıralandığında dini sebeplerin dördüncü sırada olduğu görülmüştür. Katılım bankacılığını kullanmayan kişiler ise, katılım bankacılığının ticari bankalardan farklı olmadığını düşünmektedir.

Toroman vd. (2015) çalışmalarında, Türkiye'de ve dünyada faizsiz bankacılığa ilginin artmış olduğunu fakat yeterince ilerleme kaydedemediğini ifade etmiştir. Tasarrufların direkt yatırımlara kanalize edilmesinde önemli bir rolü olan katılım bankacılığına gerekli ilgi, alaka ve farkındalığın ne düzeyde olduğunu belirlemek için mevcut ve potansiyel banka müşterilerine düzenlemiş olduğu anket sonuçlarına göre, faizsiz bankacılık hakkında yeterince bilgi sahibi olmadıkları ve bu kişilerin çoğunluğunun katılım bankaları ile çalışmanın dini açıdan zorunluluk olmadığı fikrini taşıdığı sonucuna varmıştır.

Çobankaya (2014) çalışmasında, katıım bankacılığını bankacılık sektöründeki yeri algısını araştırmıştır. Çalışma sonuçlarına göre katılım bankacılığının faizli bankacılıktan farklı olduğu fakat farklılıkların ne olduğuna yönelik bilgi düzeylerinin düşük oranda kaldığı ancak katılım bankacılığının giderek bilinirliğinin arttığı sonucuna varılmıştır. Ayrıca katılım bankalarının tercih sebepleri sıralandığında dini sebeplerin ilk sırada olmadığı tespit edilmiştir.

Özsoy vd. (2013) çalışmalarında, Katılım bankacılığının giderek bankacılık piyasasından aldığı payın arttığına dikkat çekerek Türkiye'deki katılım bankacılığının neden tercih edildiğini amaçlayan çalışmada, Bolu'da üç katılım bankasının müşterilerine tercih sebepleri anket tekniği kullanılarak sorulmuştur. Çalışmanın sonuçlarına göre katılım bankasını tercih sebepleri olarak ürün kalitesi, imaj, güven, dini ve çevresel faktörlerin olduğu sonucuna ulaşılmıştır.

Kaytancı vd. (2013) çalışmalarında, hızlı bir gelişim sürecinde olan katılım bankacılığının hem bu sürece ayak uydurması hem de faizli bankacılık ile rekabet ederek daha sağlıklı büyümesi için katılım bankacılığı müşterilerinin katılım bankaları tarafından iyi analiz ederek müşteri odaklı çalışmalarına yönelik yapılmıştır. Bu kapsamda Eskişehir ilinde 500 katılım bankası müşterisine yönelik yapılan memnuniyet anketinde akraba ve arkadaş tavsiyesi, hızlı ve esnek çözümler, personelin yatırım konusundaki danışmanlığı sıralanmış dini sebepler dördüncü sırada yer almıştır. Müşterilerin memnun kalmadığı ürünler ise; internet bankacılığı kalitesi, düşük getirili katılma hesapları sıralanmıştır. Bu sonuca göre bankaların müşterileriyle yakın ilişki kurmasının ve müşteri odaklı davranmasının önemli olduğu vurgulanmıştır.

Ramadan (2013) çalışmasında, Ürdünlü İslami banka müşterilerinin seçim kriterlerini araştırılmıştır. Banka müşterilerinin önem derecesine göre seçim kriterlerini sıralanması istendiğinde güler yüzlü hizmet, ürünlerin fiyatı, İslami imaj ilk üç sırada yer almıştır ve sadece dini sebepler nedeniyle İslami bankacılığın tercih edilmediği tespit ediliştir. Bankanın konumu, eve yâda işe yakınlık son üç sırada yer almaktadır. Ayrıca mevcut İslami banka müşterilerinin mevcut ve potansiyel ihtiyaçların ve beklentilerinin İslami bankalar tarafından düzgün tespit edilip geliştirilmesi gerektiği sonucuna varılmıştır.

Khattak ve Rehman (2010) yapmış olduğu çalışmada, Pakistan'da faaliyet gösteren i̇slami banka müşterilerinin yaş ve gelir düzeyi gibi demografik özelliklerine göre memnuniyeti ve farkındalık düzeyini analiz edilmiştir. 
Pakistan'da katılım bankacılığının müşteri portföyünün yüksek eğitimli olduğu ve orta gelirli 21-40 yaş aralığında olduğu tespit edilmiştir ve bu kişilerin diğer faizli bankalarla çalışma oranı \%67 olduğu sonucuna varılmıştır. Faizsiz bankacılığa çalışan kişilerin dini sebeplerden dolayı tercih sebebi olduğu anlaşılmıştır. Bu sonuca göre katılım bankaları müşterilerinin katılma hesabı ve cari hesap gibi faizsiz bankacılık ürünlerini kullanıp memnun olduğunu fakat diğer faizsiz bankacılık ürünlerinin farkında olmadığı sonucuna varılmıştır.

Metawa ve Almossawi (1998) çalışmalarında, İslami bankacılık dünya çapında ün kazanmasıyla birlikte birçok uluslararası banka İslami bankacılık ürünlerini de üretmeye başladığı vurgulanmış ve Ürdün'de bir İslami bankanın müşterilerine memnuniyet ve farkındalık düzeylerini tespit etmek amacıyla anket uygulanmıştır. anket sonucuna göre İslami banka müşterilerin İslami banka ürün ve hizmetlerinden memnun oldukları fakat İslami bankacılık ürünlerinden murabaha, muşaraka ve mudaraba gibi spesifik ürünlerin farkında olmadıkları sonucuna varılmıştır.

\section{VERI VE YÖNTEM}

\subsection{Kavramsal Çerçeve ve Araştırma Hipotezleri}

Bu çalışmada finansal tüketicilerin katılım bankacılığı kullanım faktörlerini etkileyen unsurların tespit edilmesi amaçlanmaktadır. Yapılan analizler neticesinde "Faizsiz Finans Kabul Modeli” adı altında bir model geliştirilmesi hedeflenmektedir. Faizsiz Finans Kabul Modeli, bireylerin katılım bankacılığı kullanımlarını etkileyen faktörlerin tahmin edilmesinde kullanılacaktır. Geliştirilecek olan bu modelde finansal tüketicilerin katılım bankacılığı kullanım davranışlarında algılanan hizmet kalitesi, algılanan dini hassasiyetler, algılanan bilinirlik, algılanan şeffafık ve güvenilirlik gibi etmenlerin kullanım tercihlerini etkileyip etkilemediği araştırılacaktır. Geçerliliği test edilecek model ve hipotezler şekil 1'de verilmiştir.

\section{Şekil 1:Faizsiz Finans Kabul Modeli}

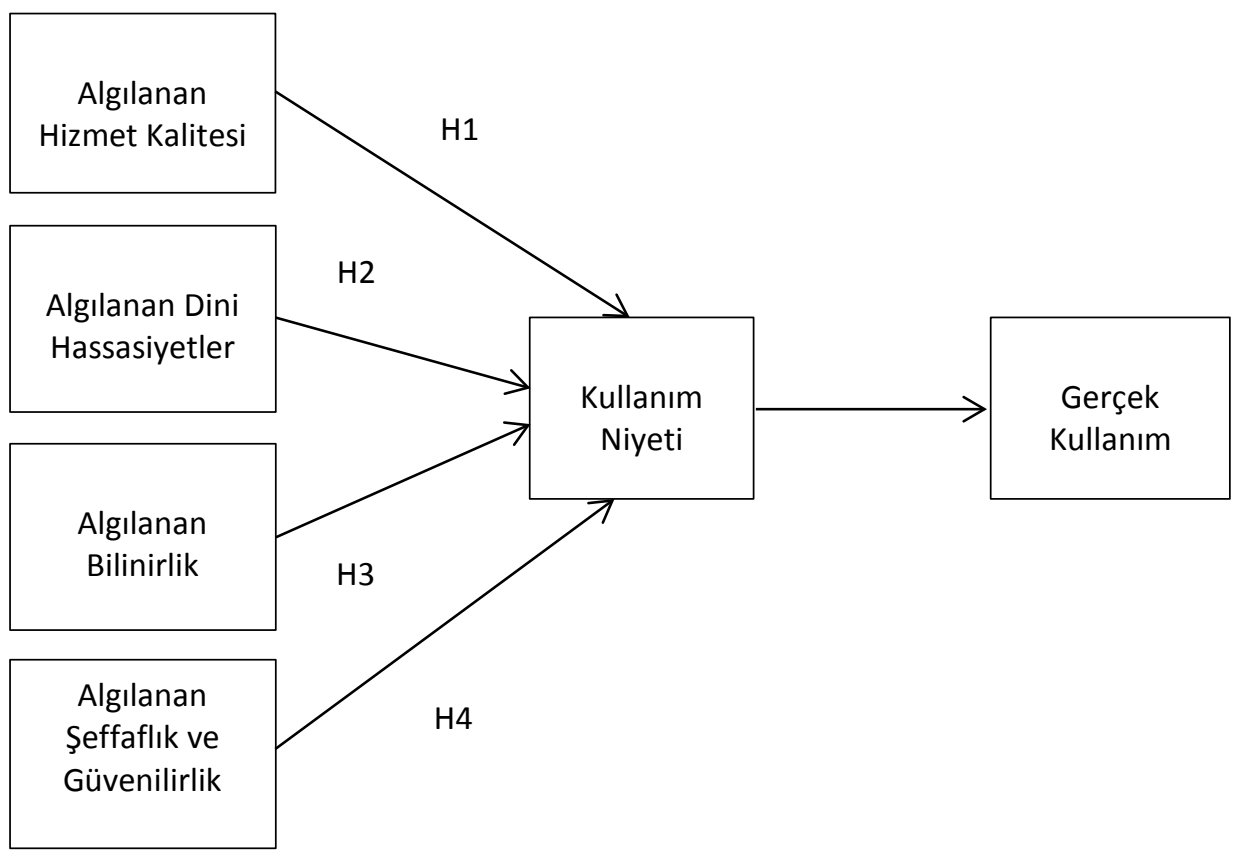

Araştırma modeline dayanılarak oluşturulan araştırma hipotezleri aşağıda verilmiştir.

Hipotez 1: Bir müşterinin hizmet kalitesi algısı katılım bankacılı̆̆ı kullanım niyetini olumlu etkilemektedir. 
Hipotez 2: Bir müşterinin dini hassasiyetler algısı katılım bankacılığı kullanım niyetini olumlu etkilemektedir. Hipotez 3: Bir müşterinin bilinirlik algısı katılım bankacılığı kullanım niyetini olumsuz etkilemektedir. Hipotez 4: Bir müşterinin şeffaflık ve güvenilirlik algısı katılım bankacılığı kullanım niyetini olumlu etkilemektedir.

\subsection{Araştırma Yöntemi}

\subsection{1.Ölçüm}

Finansal tüketicilerin katılım bankacılığı tercihlerini etkileyen faktörleri belirlemek amacıyla iki bölümlü bir anket formu hazırlanmıştır. Anketin birinci bölümünde anketi yanıtlayanların demografik özelliklerine yönelik sorular yer almaktadır. Yaş, cinsiyet, aylık gelir, katılım bankacılığı ile ilgili bilgi sahibi olma ve katılım bankacılığını kullanma gibi sorularında yer aldığı beş sorudan oluşan demografik bilgiler yer almaktadır. Anketin ikinci bölümü, algılanan hizmet kalitesi, algılanan dini hassasiyet, algılanan bilinirlik, algılanan şeffaflık ve güvenilirlik faktörlerini tespit etmeye yönelik sorulardan oluşmaktadır.

Oluşturulacak olan ölçekte değişkenlerin belirlenmesi amacıyla "Doğrulayıcı Faktör Analizi” uygulanmıştır. Kullanılan ölçeklerin tamamında 5'li likert tipi soru maddeleri yer almaktadır. Cronbach's alfa testi yardımıyla ölçekte yer alan değişkenlerin güvenilirlikleri test edilmiştir. Faktör analizde kullanılan verilerin analize uygun olup olmadığı Barlett Küresellik ve Kaiser-Meğer-Olkin (KMO) yöntemleriyle test edilmiştir.

\subsubsection{Bilgi Toplama}

Bu araştırmaya Türkiye'deki çeşitli üniversitelerde çalışan akademisyenler katılmıştır. 2016 yılında Yüksek Öğretim Kurulunun yayınlamış olduğu istatistiki bilgilere göre Türkiye genelindeki üniversitelerde 156.168 akademisyen görev yapmaktadır. \%5 hata payı ve \%99 güven düzeyinde örneklem büyüklüğü 661 kişi yapmaktadır. Örneklem yöntemi olarak kolayda örneklem yöntemi tercih edilmiştir. Katılımcılara anket formu çevrimiçi olarak gönderilmiştir. Toplam 5.600 akademisyenin mail adresine anket formu gönderilmiştir. Anketlerin 708 tanesine yanıt gelmiştir. 708 anketin tamamı analizde kullanılmıştır. Anketler SPSS paket programında analiz edilmiştir.

Tablo 1 ankete katılanların demografik dağılımlarını göstermektedir. Katılımcıların \%65'i (462) Erkek ve \%34,7'si (246) Kadın'dır. Katılımcıların yaş aralıklarına bakıldığında \%50'si (354) 31-40 yaş aralığındadır. 50 yaş ve üstü olan katılımcıların oranı \%10,2'dir. Katılımcıların aylık gelirleri incelendiğinde \%57,6'sı (408)

Tablo 1: Ankete Katılanların Demografik Yapıları

\begin{tabular}{|c|c|c|c|}
\hline Demografik Özellik & Kategori & Frekans & Yüzde (\%) \\
\hline \multirow{5}{*}{ Yaş } & $19-30$ yaş arası & 96 & 13,6 \\
\hline & 31-40 yaşında & 354 & 50,0 \\
\hline & 41-50 yaşında & 186 & 26,3 \\
\hline & 50 yaş ve üstü & 72 & 10,2 \\
\hline & TOPLAM & 708 & 100,00 \\
\hline \multirow{3}{*}{ Cinsiyet } & Kadın & 246 & 34,7 \\
\hline & Erkek & 462 & 65,3 \\
\hline & TOPLAM & 708 & 100,00 \\
\hline \multirow{5}{*}{ Aylık Geliri } & $0 \mathrm{TL}-3.000 \mathrm{TL}$ & 30 & 4,2 \\
\hline & $3.001 \mathrm{TL}-4.500 \mathrm{TL}$ & 408 & 57,6 \\
\hline & $4.501 \mathrm{TL}-6.000 \mathrm{TL}$ & 222 & 31,4 \\
\hline & 6.001 TL ve üzeri & 48 & 6,8 \\
\hline & TOPLAM & 708 & 100,00 \\
\hline
\end{tabular}


Tablo 2'de ankete katılan katılımcılara katılım bankacılığı uygulamaları hakkında bilgi sahibi olup olmadıkları ve katılım bankacılığını kullanıp kullanmadıkları sorusunun yanıtları yer almaktadır. Ankete katılanların \%56,8'i (402) katılım bankacılığı uygulamaları hakkında yeterince bilgi sahibiyim yanıtını vermişlerdir. \%28'i (198) duydum ama bilgi sahibi değilim, \%15,3'ü reklamlardan izlediğim kadarıyla bilgi sahibiyim yanıtını vermişlerdir. Hiç duymadım diyenlerin oranı ise $\% 0^{\prime}$ dır.

\section{Tablo 2: Katılım Bankacılığı Kullanımı ve Bilinirliği}

\begin{tabular}{|c|c|c|c|}
\hline & Kategori & Frekans & Yüzde (\%) \\
\hline \multirow{5}{*}{$\begin{array}{l}\text { Katılım bankacılığı } \\
\text { uygulamaları ile ilgili }\end{array}$} & Yeterince bilgi sahibiyim. & 402 & 56,8 \\
\hline & Duydum ama bilgi sahibi değilim. & 198 & 28,0 \\
\hline & Reklamlardan izlediğim kadarıyla bilgi sahibiyim. & 108 & 15,3 \\
\hline & Hiç duymadım. & 0 & 0,00 \\
\hline & TOPLAM & 708 & 100,00 \\
\hline \multirow{3}{*}{$\begin{array}{c}\text { Bir kez dahi olsa katılım } \\
\text { bankacılığı hizmetlerini } \\
\text { kullandınız mı? }\end{array}$} & Evet & 366 & 51,7 \\
\hline & Hayır & 342 & 48,3 \\
\hline & TOPLAM & 708 & 100,00 \\
\hline
\end{tabular}

\section{BULGULAR VE TARTIŞMA}

\section{1.Ölçek Doğrulama}

Kullanılan yapısal eşitlik modellerinde ele alınan her bir ölçek için tutarlılık değerleri hesaplanmaktadır. Aynı zamanda yapısal eşitlik modellerinde kullanılan güvenilirlik ve geçerlilik hesaplamaları da analize dahil edilmektedir. Kullanılan ölçeğe yönelik çeşitli analizler gerçekleştirilmiştir. Tablo 3'de çalışmada yer alan ölçek modeline yönelik değerler verilmiştir.

Tablo 3. Ölçek Modeline Ait Değerler

\begin{tabular}{|l|c|c|c|}
\hline \multicolumn{1}{|c|}{ Faktör } & Cronbach $\alpha$ & $\begin{array}{c}\text { Yapı } \\
\text { Güvenilirliği }\end{array}$ & Ortalama \\
\hline Hizmet Kalitesi &, 935 & .901 & 4.45 \\
\hline Dini Hassasiyet &, 927 & .896 & 2.43 \\
\hline Bilinirlik &, 870 & .914 & 3.75 \\
\hline Şeffaflık ve Güvenilirlik &, 850 & .835 & 4.08 \\
\hline
\end{tabular}

Her faktör için Cronbach alfa değerleri tahmin edilmiştir. Değerler 0.850-0,927 aralığında değişmektedir. Tüm ölçeklerin değeri bir ölçeğin güvenilirliğini gösteren 0.70 değerinden daha büyüktür (Nunnally and Bernstein 1994). Yapısal eşitlik modelinde güvenilirlik ve geçerlilik hesaplamalarında bakılan diğer değerlerden biri yapı güvenirliğidir. Yapı güvenilirliği sonucunun en az 0,5 veya daha fazla olması önerilmektedir (Hair et al. 2006).

Faktör analizi, analize dahil edilen tüm veri setleri için aynı uygunlukta olmayabilir. İşte bu yüzden Faktör analizde kullanılan verilerin analiz için uygun olup olmadığı Barlett Küresellik ve Kaiser-Meğer-Olkin (KMO) yöntemleriyle test edilmektedir. Kaiser-Meğer-Olkin değeri, analiz için kullanılan değişken matrisinin faktör analizine uygunluğu ve veri yapısının faktörleri tespit etmek için uygun olup olmadığı hakkında bilgi verir. 
Faktörleşebilirlik (fakctorability) için KMO'nun 0.50'den büyük olması daha doğrudur. (Field, 2000). Barlett testi, kullanılan değişkenler arasında herhangi bir ilişkinin olup olmadığını kısmı kolerasyonlar temelinde inceler. KMO değerinin 0.50'den küçük olması halinde faktör analizi yapılamaz.

Tablo 4: KMO ve Bartlett's Testi Sonuçları

\begin{tabular}{|l|l|r|}
\hline \multicolumn{3}{|c|}{ KMO and Bartlett's Test } \\
\hline \multicolumn{2}{|c|}{ Kaiser-Meyer-Olkin Measure of Sampling Adequacy. } &, 899 \\
\hline \multirow{2}{*}{$\begin{array}{l}\text { Bartlett's Test of } \\
\text { Sphericity }\end{array}$} & Approx. Chi-Square & 1816,034 \\
\cline { 2 - 3 } & $\mathrm{df}$ & 153 \\
\cline { 2 - 3 } & Sig. &, 000 \\
\hline
\end{tabular}

Tablo 4'de KMO ve Bartlett's testi sonuçları yer almaktadır. Bu çalışmada KMO değeri 0,899'dur. Buda bize veri setinin faktör analizi için daha uygun olduğunu gösterir. Bartlett testi anlamlılık değeri, 0.05 'ten düşük ise kullanılan verilerin çok değişkenli ve normal dağılımlardan elde edildiği belirtilir ve faktör analizine devam edilir.

Tablo 5'de açıklayıcı faktör analizi sonuçları verilmiştir.

Tablo 5: Açıklayıcı Faktör Analizi Sonuçları

\begin{tabular}{|l|l|l|l|l|}
\hline \multicolumn{1}{|c|}{ Faktör } & F1 & F2 & F3 & F4 \\
\hline A. Hizmet Kalitesi & & & \\
A1 & .704 & & & \\
A2 & .753 & & & \\
A3 & .786 & & & \\
A4 & .749 & & & \\
A5 & .811 & & & \\
A6 & .794 & & & \\
\hline B. Dini Hassasiyetler & & & & \\
B1 & & .857 & & \\
B2 & & .830 & & \\
B3 & & .827 & & \\
B4 & & .844 & & \\
\hline C. Bilinirlik & & & & \\
C1 & & & .872 & \\
C2 & & & .855 & \\
C3 & & & .891 & \\
C4 & & & .813 & \\
\hline D. Şeffaflık ve Güvenilirlik & & & & \\
D1 & & & & \\
D2 & & & .685 \\
D3 & & & \\
D4 & & & \\
\hline Kümülatif Açıklayıcı Varyans & 47.31 & 55.21 & 63.41 & 73.14 \\
\hline
\end{tabular}


Faktör skorlarının elde edilmesi için Varimax Dikey Döndürme tekniği kullanılmış ve faktörlerin indirgenmesi yapılmıştır. Elde edilen faktör yüklerinden 0,50'nin üzerinde olanlar tabloya eklenmiştir (Lee, 2009). Toplam Varyansın \%73'ünü açıklayan 4 faktör 18 değişken elde edilmiştir. Açıklanan varyans oranı, kullanılan ölçeğin faktör yapısının kuvvetini gösterir. Kümülatif açıklayıcı varyans oranının $\% 40$ ile $\% 60$ arasında olması yeterlidir.

\subsection{Model Testi}

Yapısal model testi sonuçları, algılanan hizmet kalitesi ile kullanım niyeti arasında; algılanan dini hassasiyetler ile kullanım niyeti arasında; algılanan bilinirlik ile kullanım niyeti arasında; algılanan şeffaflık ve güvenilirlik ile katılım bankacılığı kullanım niyeti arasında pozitif yönde ilişkinin var olduğunu göstermektedir. Şekil 2'de yapısal modelin hipotez testi sonuçları gösterilmektedir.

\section{Şekil 2: Model Testi Sonuçları}

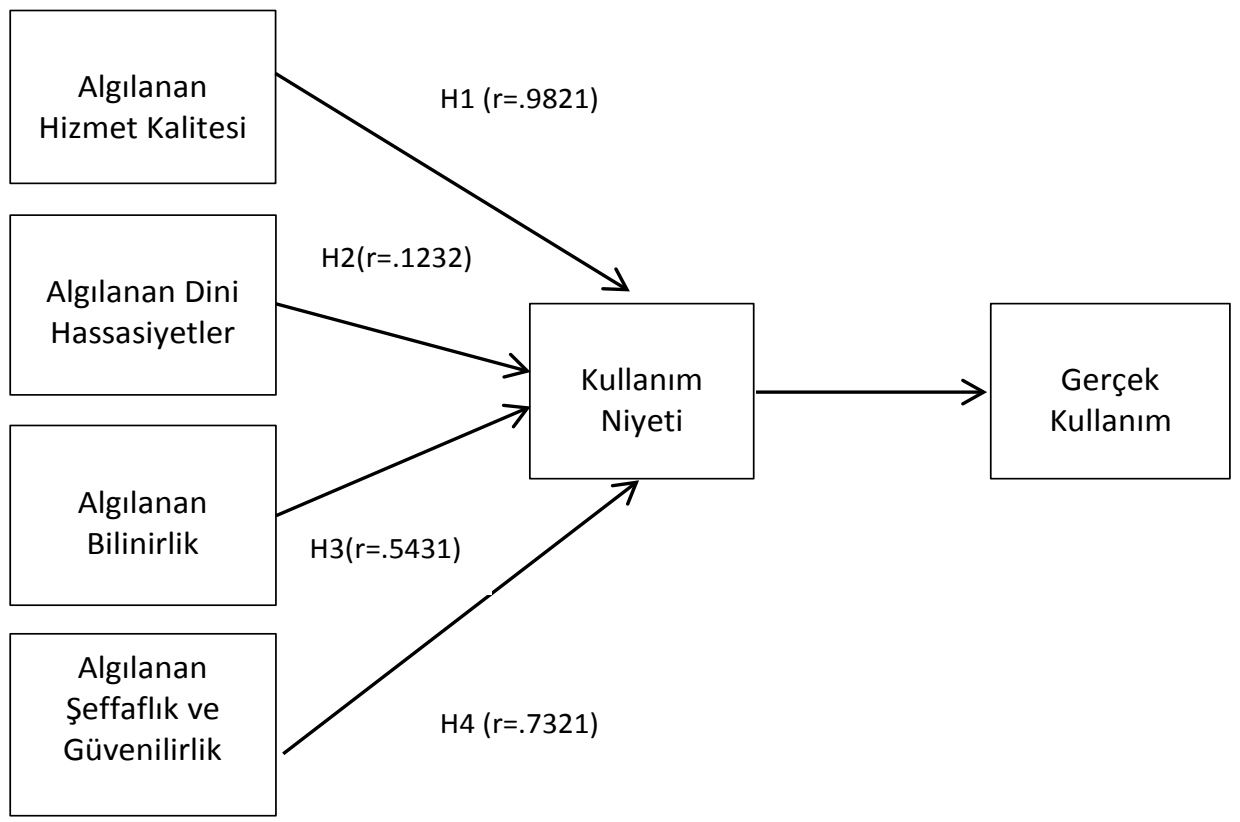

Hipotez 1 bir müşterinin hizmet kalitesi algısı ile katılım bankacılığı kullanım niyeti arasındaki ilişkiyi ortaya koymaktadır. Modele göre algılanan hizmet kalitesi ( $r=.9821)$ kullanım niyeti üzerinde anlamlı ve pozitif yönde etkisi bulunmaktadır $(\mathrm{t}=10,147)$. Hipotez 1 kabul edilmektedir.

Hipotez 2 bir müşterinin dini hassasiyetleri ile katılım bankacılığı kullanım niyetini arasındaki ilişkiyi ortaya koymaktadır. Modele göre dini hassasiyet algısının ( $r=.1232)$ kullanım niyeti üzerinde $t$ değerinin $(t=1,1425)$ anlamlı bir sonuç olmamasından dolayı bir etkisi yoktur. Hipotez 2 red edilmektedir.

Hipotez 3 bir müşterinin bilinirlik algısı ile katılım bankacılığı kullanım niyetini arasındaki ilişkiyi ortaya koymaktadır. Modele göre bilinirlik algısı $(r=.5431)$ ile kullanım niyeti arasında pozitif ve anlamlı bir ilişki vardır $(t=6,698)$. Hipotez 3 kabul edilmektedir. 
Hipotez 4 bir müşterinin şeffaflık ve güvenilirlik algısı ile katılım bankacıllı̆ı kullanım niyetini arasındaki ilişkiyi ortaya koymaktadır. Modele göre şeffaflık ve güvenilirlik algısı ( $r=.7321)$ ile kullanım niyeti arasında pozitif ve anlamlı bir etki bulunmaktadır $(\mathrm{t}=9,598)$ Hipotez 4 kabul edilmektedir.

Modelde yer alan parametrik değerler olması gereken ölçülere sahipse modelin güvenli olduğu sonucuna ulaşılmaktadır. Modelin uygunluğunun belirlenmesinde analize dahil edilen örnek büyüklüğünün etkisi vardır. (Jaafar and Rafiq, 2005).

Çalışmada oluşturulan modele ait uyum değerleri Tablo 6'de verilmiştir.

Tablo 6: Modele Ait Uyum Değerleri

\begin{tabular}{|l|l|l|}
\hline Model Uyum Değerleri & Ölçülen Değer & Kabul edilen değer \\
\hline$\chi 2 / d f$ & 1.791 & $\leq 3.00$ \\
\hline Root Mean Square Residual (RMR) & .037 & $0-1$ \\
\hline Root Mean Square Error of Approximation (RMSEA) & .0645 & $.05-.08$ \\
\hline Comparative Fit Index (CFI) & .945 & $\geq 0.90$ \\
\hline Goodness of Fit Index (GFI) & .962 & $\geq 0.90$ \\
\hline Relative Fit Index (RFI) & .931 & $\geq 0.90$ \\
\hline
\end{tabular}

Çalışmada elde edilen modelin uygunluğuna yönelik ( $\chi 2 / \mathrm{df})$ ve Root Mean Square Residual, Comparative Fit Index, Root Mean Square Error of Approximation, Relative Fit Index, Goodness of Fit Index kullanılmıştır. Tüm uyum değerleri kabul edilir sınırlar içerisindedir. Ortaya çıkan bu sonuçlar modelin kabul edilebilir özellik taşıdığını göstermektedir.

\section{SONUÇ}

$\mathrm{Bu}$ çalışmada; finansal tüketicilerin katılım bankacılı̆̆ı kullanımını etkileyen faktörlerin araştırılması amaçlanmıştır. Katılım bankacılığı kullanım faktörlerini tespit etmek amacıyla hazırlanan anket çalışması Türkiye genelinde üniversitelerde çalışan akademik personele uygulanmış ve 708 anket ile veriler elde edilmiştir. Dolaysıyla bu çalışmanın sonuçları sadece araştırma kapsamı için geçerlidir ve genellenemez.

Finansal tüketicilerin katılım bankacılığı kullanımını etkileyen faktörler faizsiz finans kabul modeli adı altında test edilmiştir. Model çerçevesinde dört hipotez geliştirilmiştir. Buna göre; algılanan hizmet kalitesi, algılanan dini hassasiyetler, algılanan bilinirlik, algılanan şeffaflık ve güvenilirlik unsurlarının katılım bankacılığı kullanım niyeti üzerindeki etkisi araştırılmıştır.

Katılım bankacılı̆̆ı kullanım modeline yönelik oluşturulan hipotezlere ayrı ayrı istatistiksel analizler uygulanmıştır. Uygulanan istatistiksel analiz sonucunda algılanan hizmet kalitesinin finansal tüketicilerin katılım bankacılığı uygulamalarını benimsemesinde en büyük etkisi olan değişken olduğu tespit edilmiştir $(r=0,9821)$. Finansal tüketicilerin katılım bankacılığını benimsemelerinde en önemli ikinci etmen ise algılanan şeffaflık ve güvenilirliktir $(r=0,7321)$. Üçüncü en önemli etmen ise bilinirliktir $(r=0,5431)$. Dini hassasiyetlerin katılım bankacılığı kullanımını etkileyen faktörler arasında en düşük etkiye sahiptir $(r=0,1232)$.

Finansal tüketicilerin dini hassasiyetleriyle katılım bankacılığı kullanım niyeti arasında pozitif bir ilişki vardır ancak bu ilişki anlamlı değildir $(\mathrm{t}=1,1425)$. Katılım bankacılığın kullanımını etkileyen faktörler arasında sanılanın 
aksine dini hassasiyetler önemli bir faktör değildir. Finansal tüketici banka tercihinde hizmet kalitesi, şeffaflık ve güvenilirlik, bilinirlik gibi faktörleri esas almaktadır.

Katılım bankaları 2015-2025 strateji belgelerine göre bankacılık sektöründeki paylarını \%15’e çıkarmayı hedeflemektedirler. Bu hedefe ulaşmak demek daha çok mevduat kabulü demektir. Daha çok mevduat demek daha çok finansal tüketicinin katılım bankalarını tercih etmesi anlamına gelir. Katılım bankalarının daha çok finansal tüketicileri bankalarıyla çalışmaya ikna edebilmeleri için; hizmet kalitesine önem vermeleri, bankacılık ürün çeşitliliğini artırmaları, şube ve ATM sayılarını artırmaları, cazip kredi ve ödeme imkanları gibi kampanyalar düzenlemeleri gerekmektedir.

Finansal tüketiciler bankaların şeffaf ve güvenilir almalarına önem vermektedirler. Ankete katılanların büyük çoğunluğu katılım bankalarının faizsiz çalışmadığına inanmaktadır. Finansal tüketici nezdinde bu olumsuz algının kırılması gerekmektedir.

\section{KAYNAKLAR}

Aldohni, A. K. 2015, "The Quest for a Better Legal and Regulatory Framework for Islamic Banking”, Ecclesiastical Law Journal, Volume 17, Issue 01, pp. 15-35.

Ariff, M. 2014, "Whither Islamic Banking?”, The World Economy, Volume 37, Issue 6, pp. 733-746.

Bellalah, M., Ellouz S. 2004, “Islamic finance, interest rates and Islamic banking: A Survey of the literature”, Finance India: special issue, 18, pp.533-546.

Çobankaya, F.T. 2014. "Katılım Bankalarının Türkiye'deki Farkındalık Düzeyinin Tespiti: Batı Akdeniz Bölgesinde Bir Araştırma”, Süleyman Demirel Üniversitesi Sosyal Bilimler Enstitüsü İşletme Anabilim Dalı Yüksek Lisans Tezi, S117

Field, A. 2000. "Discovering Statistics using SPSS for Windows", London - Thousand Oaks -New Delhi: Sage publications

Gençtürk, M., Çobankaya, F. T. (2015). Katılım Bankalarının Batı Akdeniz Bölgesindeki Farkındalık Düzeyinin Tespiti, Bankacılar Dergisi, Sayı 93, 82-105

Hair, J. F., Black, W., Anderson, R., Babin, B. R. and Tahtam, R. L. 2006. "Multivariate Data Analysis with Readings”, London: Mcmillan Book Company.

Hassan, M., Dridi, J. 2010, "The effects of the global crisis on Islamic and conventional banks: a comparative study". IMF Working Paper No. $10 / 201$.

Jaafar, H.S. and Rafiq, M. 2005. "Customers' Perceptions of Service Quality by TPL Service Providers in the United Kingdom - A Confirmatory Factor Analysis", Research Methodologies in Supply Chain Management, pp.187-202.

Kaytancı, B.G., Ergeç, E.H, Toprak, M. 2013. “801 Katılım Bankası Müşterilerinde Bankacılık Ürün ve Hizmetlerine Yönelik Memnuniyet: Türkiye Örneği", Internatıonal Conference On Eurasıan Economıes 2013, Sessıon 7C, 801-811

Khattak, N. A., Ur Rehman, K. 2010. "Customer satisfaction and awareness of Islamic banking system in Pakistan", African Journal of Business Management, Sayı 4 Cilt 5, 662-671.

Lee, M. 2009. "Factors İnfluencing The Adoption of İnternet Banking: An İntegration of TAM and TPB with Perceived Risk and Perceived Benefit", Electronic Commerce Research and Applications, 8: pp.130-141.

Mallin, C., Faraga, H., Yonga, K. 2014. "Corporate social responsibility and financial performance in Islamic banks", Journal of Economic Behavior \& Organization 103, pp.21-S38.

Metawa, S. A., Almossawi, M. 1998. "Banking behavior of Islamic Bank Customers: Perspectives and İmplications", International Journal of Bank Marketing, Sayı 16, Cilt 7, 299-313.

Mghaieth, A., Mehdi, I.K.E. 2014, "The determinants of cost/profit efficiency of Islamic banks before, during and after the crisis of 20072008 using SFA approach", IPAG working papers, http://www.ipag.fr/fr/accueil/la-recherche/publications-WP.html

Nunnally, J. C., Bernstein, I. H. 1994. “Psychometric theory”, McGraw, New York: McGraw-Hill. 
Özsoy, I., Görmez, B., Melik, S. 2013. "Türkiye'de Katılım Bankalarının Tercih Edilme Sebepleri: Ampirik Bir Tetkik", Celal Bayar Üniversitesi Yönetim ve Ekonomi Dergisi, Sayı 1, Cilt 10, 187-206

Ramadan, Z. S. 2013. "Jordanian Criteria for Islamic Banks Selection: Evidence From The Jordanian Banking Sector". International Journal of Academic Research in Accounting, Finance and Management Sciences, Sayı 3, Cilt 3, 139-145.

Sermaye Piyasaları Araştırma ve Uygulama Merkezi. 2013. "islami Finans Kavramı, Ürünler, Dünyada ve Türkiye’de Gelişimi ve Geleceği”. SERPAM.

Smola, E., Mirakhor, A. 2010, "The Global Financial Crisis and Its Implications for the Islamic Financial Industry", International Journal of Islamic and Middle Eastern Finance and Management, 3, (4), pp. 372-385.

Toroman, C., Ata, H.A., Buğan, M.F. 2015, "İslami Bankaclık Faaliyetlerine Yönelik Müşteri Algısı Üzerine Bir Araştırma", Gaziantep University Journal of Social Sciences, Sayı 14, Cilt 4, 761-779,

Türkiye Katııım Bankaları Birliği 2016. “Katılım Bankaları Aktif Büyüklüğü Veri Seti”, http://www.tkbb.org.tr/veri-seti. Erişim: 29.03.2016 


\section{Ek - Anket}

Bölüm. 1

A. Yaş

(19-30 yaş / 31-40 yaş / 41-50 yaş / 50 yaş üstü)

B. Cinsiyet

(Kadın / Erkek)

C. Aylık Geliriniz

( 0-3000 TL/ 3001-4500 TL/ 4501-6000 TL/ 6001 TL ve üzeri

D. Katılım Bankacılı̆ıı uygulamaları ile ilgili;

Yeterince bilgi sahibiyim

Duydum ama bilgi sahibi değilim

Reklamlarda izlediğim kadarıyla bilgi sahibiyim

Hiç duymadım

E. Bir kez dahi olsa Katıım Bankacılığı hizmetlerini kullandınız mı? (Cari hesap, Katılım hesabı, Finansman desteği, Kredi kartı, Banka kartı, havale, EFT, Kiralık kasa, ATM vb.)

Hayır, Hiç Kullanmadım

Evet Kullandım

Bölüm. 2

A. Algılanan Hizmet Kalitesi

A.1 Katılım bankalarının hizmet kalitesi katılım bankalarını tercih etmemi etkiler.

A.2 Katılım bankalarının bankacılık ürün çeşitliliği katılım bankalarını kullanımımı etkiler.

A.3 Banka şubelerinin sayısı ve şubeye ulaşım katılım bankalarını tercih etmemi kolaylaştııı.

A.4 Yakınlarımda bankanın ATM'si bulunursa katılım bankacılı̆̆ını kullanabilirim.

A5 Üniversite kampüsünde şube ve ATM'sinin olması katılım bankacılı̆̆ı tercihimi olumlu etkiler.

A6 Cazip kredi ve ödeme imkânları olursa katılım bankalarını tercih ederim.

B. Algilanan Dini Hassasiyetler

B.1 İslami esaslara göre çalışması katılım bankalarını tercih etmemi etkiler.

B.2 Bankaların faizli yâda faizsiz olarak çalışması benim için önemlidir.

B.3 Katıım bankalarının İslami esaslara göre çalışması yatııı kararlarımı etkiler.

B.4 Birikintilerimi İslami esaslara göre çalışan bir bankada değerlendirmek benim için önemlidir.

C. Algılanan Bilinirlik

C.1 Kitlesel iletişim araçlarındaki reklamlar katılım bankacılığı tercihimi olumlu etkiler.

C.2 Katılım bankalarının imaj ve popülaritesi katııım bankalarını tercih etmemi kolaylaştıır.

C.3 Katılım bankacılığı ürün ve hizmetleri hakkında bilgi sahibi olursam katııım bankalarını tercih edebilirim.

C.4 Katılım bankalarının fon kullandırma yöntemleri hakkında bilgi sahibi olursam katılım bankalarından finansman desteğ (kredi) kullanabilirim.

D. Algılanan Şeffaflık ve Güvenilirlik

D.1 Katııım bankalarının güvenilir olması katılım bankalarını kullanımımı etkiler.

D.2 Katılım bankaları bankacılık işlemlerinde her zaman şeffaftır.

D.3 Katııım bankalarııı faizsiz çalışıı̆ına inanııım.

D.4 Katılım bankaları tüm bankalar içerisinde en güvenilir bankalardır. 